\title{
HORATIA BOURGUIGNAT, 1887: IS THIS GENUS REALLY PHYLOGENETICALLY VERY CLOSE TO RADOMANIOLA SZAROWSKA, 2006 (CAENOGASTROPODA: TRUNCATELLOIDEA)?
}

\author{
MAGDALENA SZAROWSKA, ANDRZEJ FALNIOWSKI
}

Department of Malacology, Institute of Zoology, Jagiellonian University, Gronostajowa 9, 30-387 Cracow, Poland (e-mail: andrzej.falniowski@uj.edu.pl)

ABSTRACT: Horatia Bourguignat, 1887 was the first genus established for hydrobiid snails with valvatoid shell, and numerous valvatoid-shelled hydrobioids were classified as Horatia. The genus was the type one for some tribe/family-rank taxa. Thus it is one of the "crucial" hydrobiid genera. Horatia seems to inhabit only Croatia and Macedonia, and its type species: H. klecakiana Bourguignat, 1887, inhabits the springs in the Cetina River Valley. In the present paper the shell, operculum, soft part pigmentation, protoconch SEM microsculpture, female reproductive organs, and penis of $H$. klecakiana from the spring Studenci, N of Kučiće, in the valley of the Cetina River, Croatia, are described, to confirm the identity of the studied specimens with this species. Mitochondrial cytochrome oxidase subunit I (COI) and nuclear 18S ribosomal RNA gene sequences are used to infer phylogenetic relationships of Horatia, especially with Radomaniola and the sequence of Horatia from GenBank. The results suggest close relationships of the genus with Sadleriana, not with Radomaniola.

KEY WORDS: Truncatelloidea, COI, 18S rRNA, protoconch, anatomy, molecular phylogeny

\section{INTRODUCTION}

BOURGUIGNAT (1887) described a new genus Horatia, with its type species H. klecakiana Bourguignat, 1887, from "sorgente près de Ribaric, dans la vallée de Cetina” in Croatia. RADOMAN (1983) identified this type locality with the Vrijovac spring in the source area of the Cetina River. Horatia was the first nominal genus described for the European hydrobiids with valvatiform shell (BODON et al. 2001). Thus, it is one of the "crucial" hydrobiid genera. For example, TAYLOR (1966) established Horatiini as tribe in Hydrobiidae, within the subfamily Cochliopinae, and BOLE (1993) established a distinct family Horatiidae. RADOMAN (1973) included Horatia in Orientalinidae. KABAT \& HERSHLER (1993) presented a review of understanding of this genus in the literature. RADOMAN (1983) listed three species of Horatia from the former Yugoslavia: H. klecakiana, $H$. novoselensis Radoman, 1966, and H. macedonica (Kuščer, 1936).
Species of Horatia were reviewed by SCHÜTT (1961), BOETERs $(1974,1998)$ and Bole (1993). According to ANGELOV (1967) Horatia is known from Bulgaria as well, but this seems doubtful.

In fact, there is a number of valvatiform hydrobiid snails, often minute in size, and with hardly known anatomy, many of them assigned to Horatia. Horatia sturmi (Rosenhauer, 1856) from Spain (= Boetersiella sturmi: ARCONADA \& RAMOS 2001) could be an example. Another "Horatia" described from Greece, H. hadei (GITTENBERGER 1982) belongs to the genus Daphniola Radoman, 1973 (FALNIOWSKI \& SZAROWSKA 2011a). Anyway, the identity and the phylogenetic position of the "real" Horatia remain enigmatic.

WILKE et al. (2001), applying molecular data, inferred phylogenetic position of Horatia, very close to Radomaniola, and the same was confirmed in recent 
study (WILKE et al. 2013). However, this placement raises doubts. The single sequence in GenBank, used several times, also in our studies (e.g. SZAROWSKA 2006, FALNIOWSKI \& SZAROWSKA 2011b, SZAROWSKA \& FALNIOWSKI 2011), always with the same placing of Horatia very close to Radomaniola Szarowska, 2006, was intriguing. As co-authors of the study of WILKE et al. (2001), introducing this sequence, and thus co-authors of this possible error, we felt obliged to check the morphology of Horatia klecakiana from the Cetina Valley, to confirm that it belongs to this species, then to check if its cytochrome oxidase subunit I (COI) sequence might represent the same species as the sequence of Horatia in GenBank, and, finally, to infer its phylogenetic relationships using molecular data.

\section{MATERIAL AND METHODS}

About twenty specimens of Horatia klecakiana were collected, using a sieve $(0.5 \mathrm{~mm}$ mesh diameter), from the spring Studenci, $\mathrm{N}$ of Kučiće, in the valley of the Cetina River, Croatia, $43^{\circ} 26^{\prime} 41.3^{\prime \prime} \mathrm{N}$, $16^{\circ} 48^{\prime} 25.5^{\prime \prime} \mathrm{E}, 45 \mathrm{~m}$ a. s. 1., on the 21 st of June 2011.

Snails were washed twice in $80 \%$ ethanol and left to stand in it for around 12 hours. Then the ethanol was changed twice more within 24 hours and finally, after a few days, the $80 \%$ solution was replaced with a $96 \%$ one, in which the samples were stored at $-20^{\circ} \mathrm{C}$. The shells were photographed with a CANON EOS 50D digital camera. Five adult males and five females were dissected, using a NIKON SMZ-U stereoscope microscope. The penis and female genitalia (pallial oviduct) were examined using a MOTIC light microscope. The protoconch (after ultrasonic cleaning) was examined using a JEOL JSM-5410 scanning electron microscope, applying the techniques described by FALNIOWSKI (1990).

DNA was extracted from foot tissue of seven specimens not presented in the photographs. The tissue was hydrated in TE buffer $(3 \times 10 \mathrm{~min}$. $)$; then total genomic DNA was extracted with the SHERLOCK extracting kit (A\&A Biotechnology), and the final product was dissolved in $20 \mu \mathrm{l}$ TE buffer. The PCR reaction was performed with the following primers: LCO1490 (5'-GGTCAACAAATCATAAAGATATTGG-3') (FOLMER et al. 1994) and COR722b (5'-TAAACTTCAGGGTGACCAAAAAATYA-3') (WILKE \& DAVIS 2000) for the cytochrome oxidase subunit I (COI) mitochondrial gene and SWAM18SF1 (5'-GAATGGCTCATTAAATCAGTCGAGGTTCCTTAGATGATCCAAATC-3'), and SWAM18SR1 (5'-ATCCTCGTTAAAGGGTTTAAAGTGTACTCATTCCAATTACGG AGC-3') for the 18S rRNA gene (PALUMBI 1996). The PCR conditions were as follows: COI - initial denaturation step of $4 \mathrm{~min}$ at $94^{\circ} \mathrm{C}$, followed by 35 cycles of $1 \mathrm{~min}$ at $94^{\circ} \mathrm{C}, 1 \mathrm{~min}$ at $55^{\circ} \mathrm{C}, 2 \mathrm{~min}$ at $72^{\circ} \mathrm{C}$, and a final extension of $4 \mathrm{~min}$ at $72^{\circ} \mathrm{C} ; 18 \mathrm{~S}$ - initial denaturation step of $4 \mathrm{~min}$ at $94^{\circ} \mathrm{C}$, followed by 40 cycles of $45 \mathrm{~s}$ at $94^{\circ} \mathrm{C}, 45 \mathrm{~s}$ at $51^{\circ} \mathrm{C}$, 2 min at $72^{\circ} \mathrm{C}$ and, after all cycles were completed, an additional elongation step of $4 \mathrm{~min}$ at $72^{\circ} \mathrm{C}$ was performed. The total volume of each PCR reaction mixture was $50 \mu \mathrm{l}$. To check the quality of the PCR products $10 \mu \mathrm{l}$ of the PCR product was run on $1 \%$ agarose gel. The PCR products were purified using Clean-Up columns (A\&A Biotechnology) and were then amplified in both directions (HILLIS et al. 1996) using BigDye Terminator v3.1 (Applied Biosystems), following the manufacturer's protocol and with the primers described above. The sequencing reaction products were purified using ExTerminator Columns (A\&A Biotechnology); DNA sequences then underwent electrophoresis on an ABI Prism sequencer. The sequences were deposited in GenBank (Table 1).

Five sequences of COI of Radomaniola from the GenBank (WiLKE et al. 2001, FALNIOWSKI et al. 2012) were used, together with the one of Horatia from GenBank, and of our Horatia were used to calculate pairwise p-distances with MEGA5.10 (TAMURA et al. 2011). MEGA was also used to infer maximum likelihood (ML) tree, with the same methodology as described below.

In the phylogeny reconstruction, we used sequences from 29 rissooid taxa from GenBank (Table $1)$. Seven of them, used as an outgroup, represented the main non-hydrobiid lineages within the Rissooidea (WILKE et al. 2001); the other seven taxa represented the Hydrobiinae (including "Pyrgulinae": SZAROWSKA et al. 2005). The remaining taxa were chosen to represent all the main lineages within the European Sadlerianinae (SZAROWSKA 2006).

The COI sequences were aligned by eye using BioEdit 5.0.0 (HALL 1999) and edited with MACCLADE 4.05 (MADDISON \& MADDISON 2002). For 18S, an initial alignment was performed using CLUSTALX 1.82 (THOMPSON et al. 1997) and edited with MACCLADE. Mutational saturation for the COI dataset was examined by plotting the numbers of transitions and transversions for all the codon positions together, and for the 3rd position separately, against the percentage sequence divergence, using DAMBE 5.2.9 (XIA 2000). We also used DAMBE 5.2.9 to perform the saturation test (XIA et al. 2003). It revealed a significant degree of saturation in the third position of the sequences. In rissooids, COI approaches saturation with about $18.6 \%$ or 120 nucleotide differences (DAVIS et al. 1998), which seems to happen after approximately 10 million years. However, to avoid a substantial loss of information in the case of closely related species, this position was not excluded from the dataset and it was used for the analysis. In fact, the analysis conducted on 2nd and 3rd position only resulted in similar deep 
Table 1. Taxa used for phylogenetic analyses, with their GenBank Accession Numbers and references

\begin{tabular}{|c|c|c|c|}
\hline Species & 18S GB\# & COI GB\# & References \\
\hline Adriohydrobia gagatinella (Küster, 1852) & AF367657 & AF317881 & WILKE \& FALNIOWSKI (2001) \\
\hline Adrioinsulana conovula (Frauenfeld, 1863) & AF367656 & AF367628 & WILKE et al. (2001) \\
\hline Agrafia wiktori Szarowska et Falniowski, 2011 & JF906758 & JF906762 & SZAROWSKA \& FALNIOWSKI (2011) \\
\hline Alzoniella finalina Giusti et Bodon, 1984 & AF367686 & AF367650 & WILKE et al. (2001) \\
\hline Anagastina zetavalis (Radoman, 1973) & EF070622 & EF070616 & SZAROWSKA (2006) \\
\hline Bithynia tentaculata (Linnaeus, 1758) & AF367675 & AF367643 & WILKE et al. (2001) \\
\hline Boleana umbilicata (Kuščer, 1932) & JX982797 & JX982795 & FALNIOWSKI \& SZAROWSKA (2012) \\
\hline Bythinella austriaca (Frauenfeld, 1857) & AF212917 & FJ545132 & FALNIOWSKI et al. (2009) \\
\hline Bythiospeum sp. & AF367664 & AF367634 & WiLKE et al. (2001) \\
\hline Dalmatinella fluviatilis Radoman, 1973 & KC344539 & KC344541 & FALNIOWSKI \& SZAROWSKA (2013) \\
\hline Daphniola graeca Radoman, 1973 & EF070624 & EF070618 & SZAROWSKA (2006) \\
\hline Dianella thiesseana (Kobelt, 1878) & AY676125 & AY676127 & SZAROWSKA et al. (2005) \\
\hline Graecoarganiella parnassiana Falniowski et Szarowska, 2011 & JN202341 & JN202348 & FALNIOWSKI \& SZAROWSKA (2011b) \\
\hline Graziana alpestris (Frauenfeld, 1863) & AF367673 & AF367641 & WILKE et al. (2001) \\
\hline Grossuana codreanui (Grossu, 1946) & EF061916 & EF061919 & SZAROWSKA et al. (2007) \\
\hline Hauffenia tellinii (Pollonera, 1898) & AF367672 & AF367640 & WiLKE et al. (2001) \\
\hline Heleobia dalmatica (Radoman, 1974) & AF367661 & AF367631 & WILKE et al. (2001) \\
\hline Horatia klecakiana Bourguignat, 1887 & KJ159127 & KJ159128 & present study \\
\hline "Horatia" sturmi (Rosenhauer, 1856) & AF212912 & AF213345 & WILKE et al. (2000) \\
\hline Hydrobia acuta (Draparnaud, 1805) & AF367680 & AF278808 & WILKE \& DAVIS (2000) \\
\hline Islamia piristoma Bodon et Cianfanelli, 2001 & AF367671 & AF367639 & WILKE et al. (2001) \\
\hline Lithoglyphus naticoides (C. Pfeiffer, 1828) & AF367674 & AF367642 & WILKE et al. (2001) \\
\hline Marstoniopsis insubrica (Küster, 1853) & AF367676 & AY027813 & FALNIOWSKI \& WILKE (2001) \\
\hline Pseudamnicola lucensis (Issel, 1866) & AF367687 & AF367651 & WILKE et al. (2001) \\
\hline Pyrgula annulata (Linnaeus, 1767) & AY676124 & AY341258 & SZAROWSKA et al. (2005) \\
\hline Radomaniola callosa (Paulucci, 1881) & AF367685 & AF367649 & WILKE et al. (2001) \\
\hline Rissoa labiosa (Montagu, 1803) & AY676126 & AY676128 & SZAROWSKA et al. (2005) \\
\hline Sadleriana fluminensis (Küster, 1853) & AF367683 & AY273996 & WiLKE et al. (2001) \\
\hline Trichonia kephalovrissonia Radoman, 1973 & EF070630 & EF070619 & SZAROWSKA (2006) \\
\hline Ventrosia ventrosa (Montagu, 1803) & AF367681 & AF118335 & WiLKE \& DAVIS (2000) \\
\hline
\end{tabular}

phylogeny, but with several polytomies within more terminal nodes.

Initially, we performed phylogeny reconstruction for $18 \mathrm{~S}$ and COI data separately, using the maximum likelihood (ML) technique. Next, the partition homogeneity test (FARRIS et al. 1995) was performed (1,000 replicates) with PAUP*4.0b10 (SWOFFORD 2002), to check whether the two genes could be analysed together. Since $p>0.783$, the maximum likelihood heuristic search was then run for the combined molecular data. Following the recommendations of POSADA \& BUCKLEY (2004) and SOBER (2002), the best model for each dataset was chosen using the Akaike Information Criterion (AIC) and Bayesian Information Criterion (BIC); both chose the same model. We performed ML analyses in PAUP* and used a heuristic search strategy with stepwise addition of taxa, 10 random-sequence addition replicates, and tree-bisection-reconnection (TBR) branch swap- ping (SWOFFORD et al. 1996), and with MEGA5.10 (TAMURA et al. 2011). Nodal support was estimated using the bootstrap (BS) approach (FELSENSTEIN 1985). Bootstrap values for ML trees were calculated using 10,000 bootstrap replicates, with MEGA5.10 and the same model parameters as for ML analysis.

\section{RESULTS}

Shell (Figs 1-6) minute, valvatiform, with rapidly growing whorls, continuous peristome and slit-like umbilicus, whitish and translucent; operculum orange.

Mantle intensively pigmented black (Figs 1,4 ), or its pigmentation is less intensive (Figs $3,5,6$ ), there is nearly no pigment on the head, eyes are present.

Protoconch (Fig. 7) formed by about 1/1/4 whorl, its sculpture regular and characteristic (Figs 8-9). 


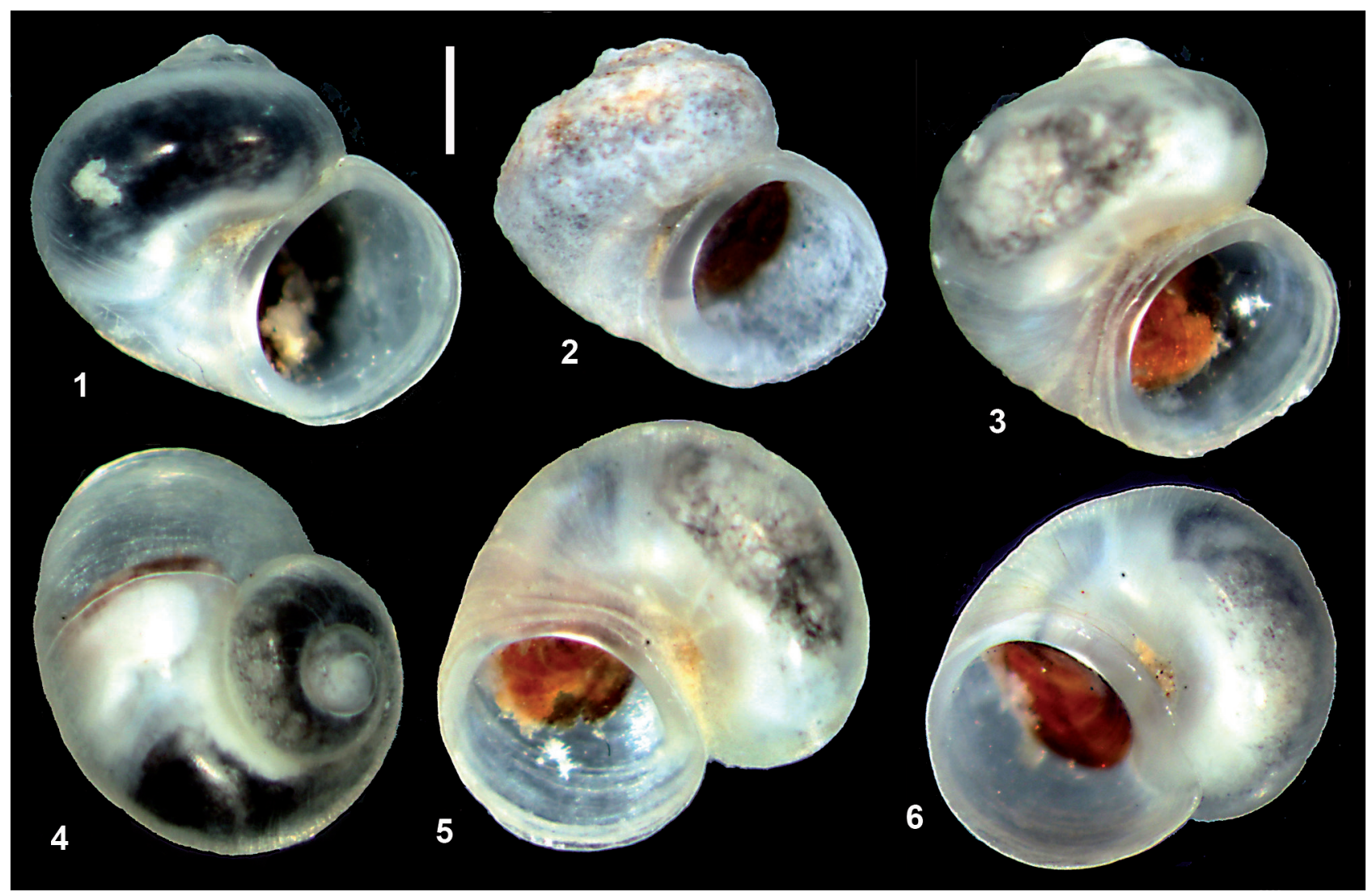

Figs 1-6. Shells of Horatia klecakiana, scale bar equals $0.5 \mathrm{~mm}$

Female reproductive organs (Fig. 10) with two moderately big receptacula, $\mathrm{rs}_{1}$ somewhat bigger than $\mathrm{rs}_{2}$. Bursa copulatrix big, pear-shaped, with long duct. Loop of "renal" oviduct massive. Penis (Fig. 11) with sharp tip and a bi-lobed outgrowth on its left side, vas deferens visible inside, running nearly straight.

Seven sequences of cytochrome oxidase subunit I (COI) were identical - there was no intrapopulation variability. There was also no variability between $18 \mathrm{~S}$ sequences.

Pairwise p-distances between COI sequences of our Horatia, five species of Radomaniola, and the sequence of Horatia from GenBank (Table 2) were characteristic of the species level between all the species of Radomaniola and between all of them and Horatia from GenBank, but more than twice higher between all six species and our Horatia. In the inferred ML tree (with the model of Tamura 3-parameter $+\Gamma$ ) Horatia from the GenBank clustered within the Radomaniola group (Fig. 12), and the bootstrap support for the clade including all the species but our Horatia was as high as $81 \%$.

For the combined data set the Bayesian Information Criterion (BIC) and corrected Akaike Information Criterion (AICc) with MEGA5 found
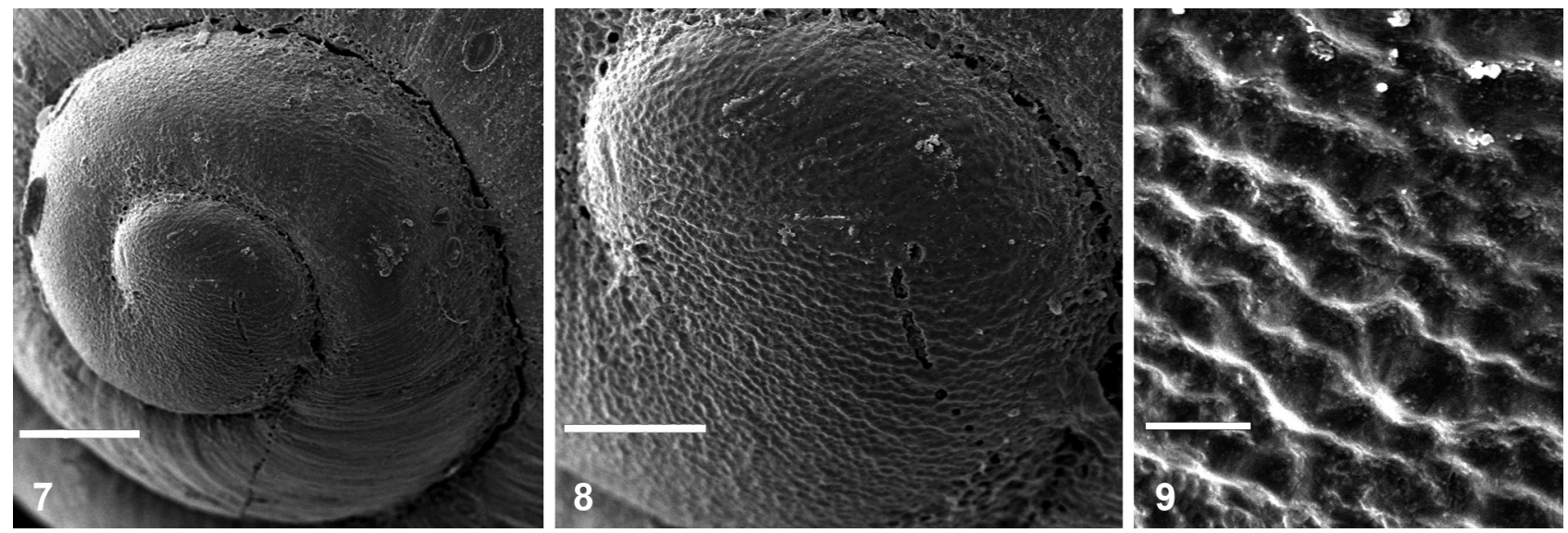

Figs 7-9. Protoconch of Horatia klecakiana, scale bars equal $100 \mu \mathrm{m}, 50 \mu \mathrm{m}$ and $5 \mu \mathrm{m}$, respectively 

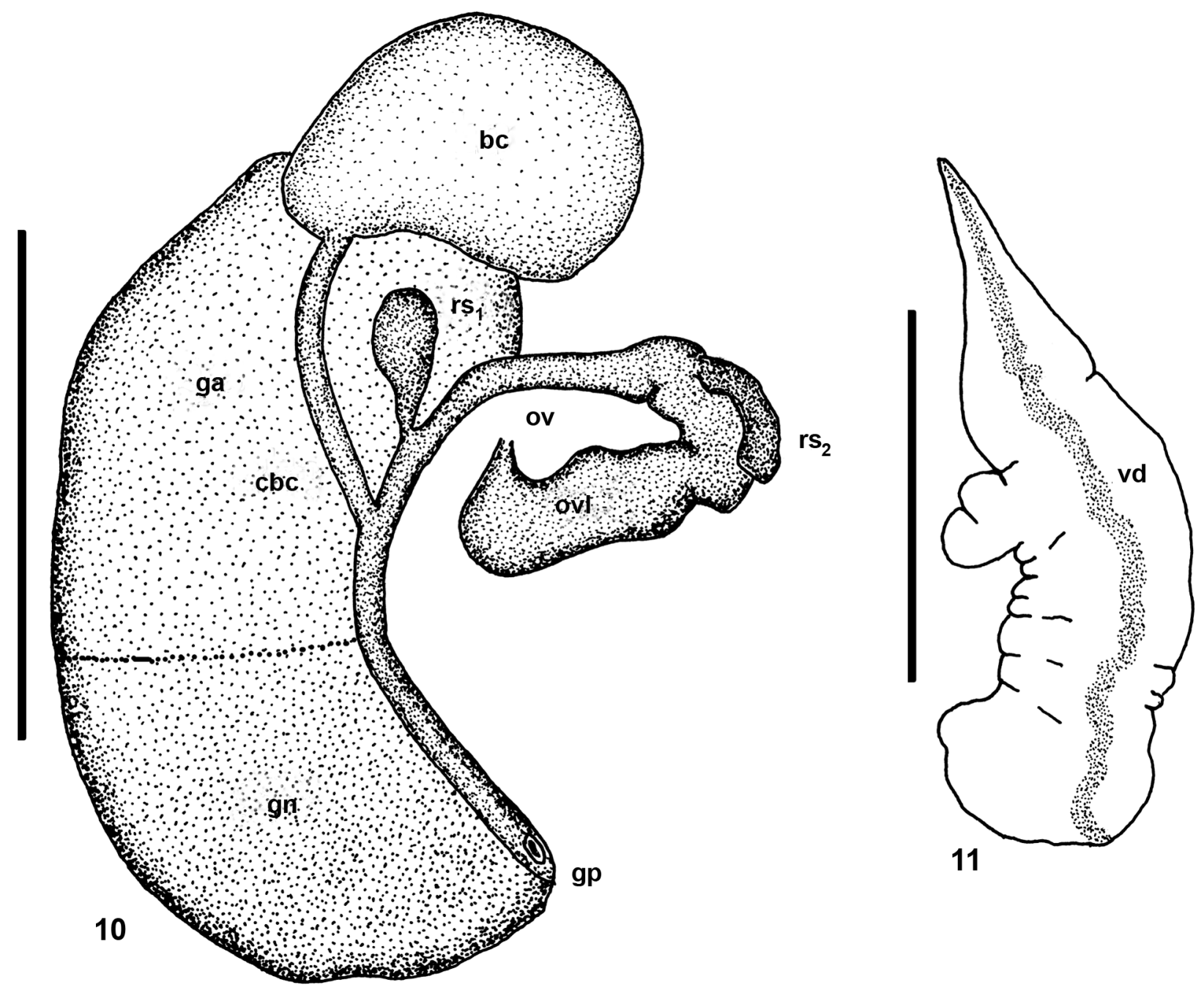

Figs 10-11. Horatia klecakiana: 10 - female reproductive organs (bc - bursa copulatrix, cbc - duct of bursa copulatrix, ga albuminoid gland, gn - nidamental gland, gp - gonoporus, ov - oviduct, ovl - loop of oviduct, $\mathrm{rs}_{1}, \mathrm{rs}_{2}-$ receptaculum seminis 1 and 2, respectively); 11 - penis (vd - vas deferens); scale bars equal $0.5 \mathrm{~mm}$

model TN93 (Tamura-Nei 1993 - NEI \& KUMAR 2000) $+I+\Gamma$, with base frequencies: $A=0.259, C$ $=0.209, \mathrm{G}=0.222, \mathrm{~T}=0.310$; substitution rate matrix: $[\mathrm{A}-\mathrm{C}]=0.031,[\mathrm{C}-\mathrm{A}]=0.038,[\mathrm{~A}-\mathrm{G}]=0.134$, $[\mathrm{G}-\mathrm{A}]=0.157,[\mathrm{~A}-\mathrm{T}]=0.045$, [T-A $]=0.038$, $[\mathrm{C}-$ $\mathrm{G}]=0.033,[\mathrm{G}-\mathrm{C}]=0.031,[\mathrm{C}-\mathrm{T}]=0.248,[\mathrm{~T}-\mathrm{C}]=$ $0.167,[\mathrm{G}-\mathrm{T}]=0.045,[\mathrm{~T}-\mathrm{G}]=0.033$; proportion of invariable sites: $(\mathrm{I})=0.63, \Gamma$ distribution with the shape parameter $=0.68$, and transition/transversion bias $\mathrm{R}=2.37$.

The inferred phylogram (Fig. 13) obviously does not confirm that Boetersiella sturmi, previously known as Horatia (and the only "Horatia" apart from $H$. klecakiana whose sequence could be found in GenBank), belongs to the genus Horatia: its closest taxa are Alzoniella Giusti et Bodon, 1984, and

Table 2. Pairwise p-distances between COI sequences of five species of Radomaniola, "Horatia klecakiana" from GenBank, and our H. klecakiana. GenBank accession numbers after WILKE et al. (2001), FALNIOWSKI et al. (2012) and present study

\begin{tabular}{|c|c|c|c|c|c|c|}
\hline & 1 & 2 & 3 & 4 & 5 & 6 \\
\hline \multicolumn{7}{|l|}{ 1. AF367649 Radomaniola callosa } \\
\hline 2. KC011803 Radomaniola montana & 0.0453 & & & & & \\
\hline 3. KC011809 Radomaniola curta anagastica & 0.0489 & 0.0399 & & & & \\
\hline 4. KC011810 Radomaniola curta curta & 0.0471 & 0.0453 & 0.0054 & & & \\
\hline 5. KC011814 Radomaniola curta narentana & 0.0435 & 0.0380 & 0.0362 & 0.0417 & & \\
\hline 6. AF367637 "Horatia klecakiana" & 0.0507 & 0.0634 & 0.0562 & 0.0507 & 0.0634 & \\
\hline 7. KJ159128 Horatia klecakiana & 0.1721 & 0.1558 & 0.1522 & 0.1522 & 0.1649 & 0.1612 \\
\hline
\end{tabular}




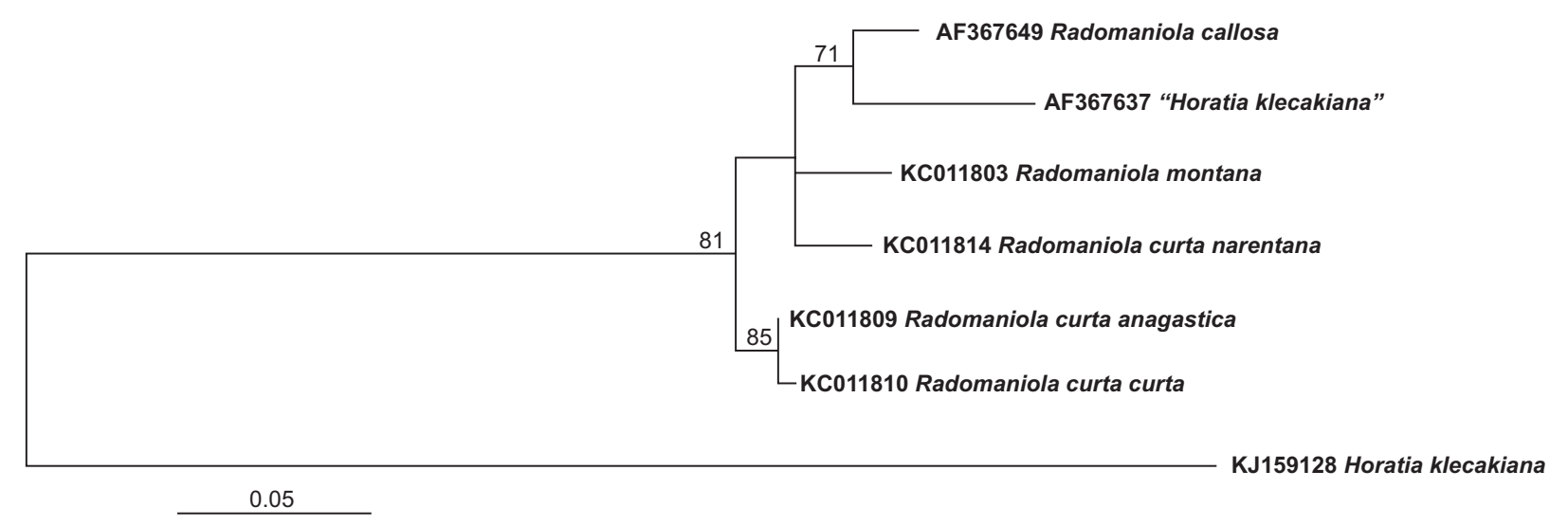

Fig. 12. Maximum likelihood tree of COI sequences for five species of Radomaniola, "Horatia klecakiana" from GenBank, and our H. klecakiana. GenBank accession numbers after WILKE et al. (2001), FALNIOWSKI et al. (2012) and present study

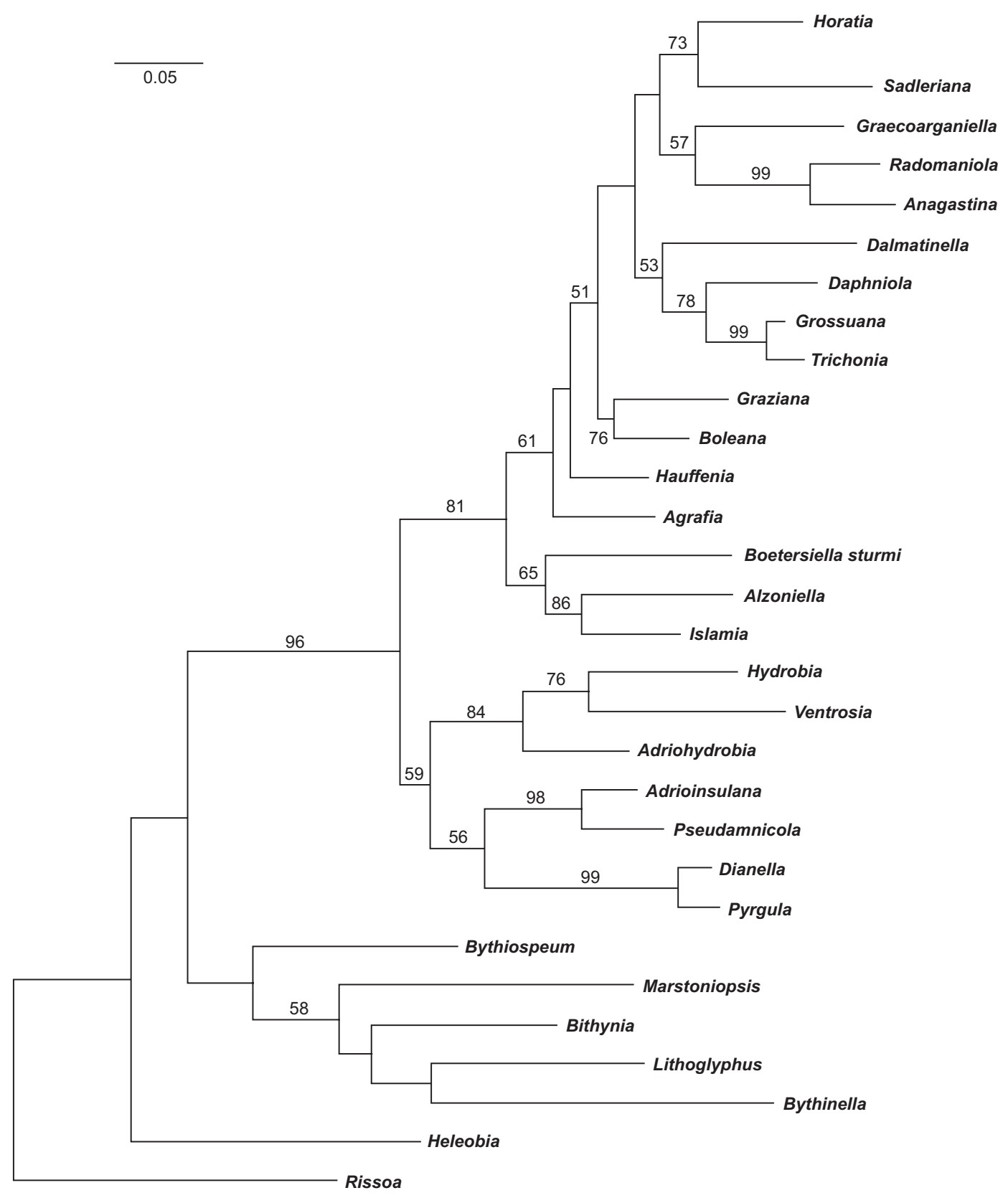

Fig. 13. Maximum likelihood tree of the two concatenated sequences (18S and COI), bootstrap supports (10,000 replicates) given if $>50 \%$ 
Islamia Radoman, 1973. Horatia belongs to the family Hydrobiidae (bootstrap support 96\%), and to the subfamily Sadlerianinae Szarowska, 2006 (bootstrap support $81 \%$ ), certainly not to Cochliopidae (represented by Heleobia Stimpson, 1865). Horatia belongs to the same clade with Sadleriana (bootstrap support 73\%). Radomaniola forms a distinct clade with Anagastina Radoman, 1973, and Graecoarganiella Falniowski et Szarowska, 2011 (although the bootstrap support is low: $57 \%$ ). The bootstrap support of the clade common to our Horatia and Radomaniola is as low as $29 \%$.

\section{DISCUSSION}

The shells and opercula resemble the ones presented and described for H. klecakiana by SCHÜTT (1961), BOETERS (1974), RADOMAN (1983), BOLE (1993) and BODON et al. (2001). There is a protoconch of H. klecakiana presented by BODON et al. (2001); however, nothing but some diatoms can be seen on it.

Both the female reproductive organs and the penis resemble the ones drawn and described by BOETERS (1974), RADOMAN (1983), BOLE (1993) and BODON et al. (2001). RADOMAN (1983) presented a wide range of variability of the penis in $\mathrm{H}$. klecakiana. All the morphological data confirm the assignment of our specimens to the type species of the genus Horatia. This, coupled with as many as seven specimens sequenced, all of them identical, strengthens our results.

Molecular data confirm that $H$. klecakiana belongs to the Hydrobiidae, not Cochliopidae as suggested by
TAYLOR (1966), and it belongs to Sadlerianinae, as proposed by SZAROWSKA (2006). Both p-distances' values and ML tree for Radomaniola, our Horatia, and Horatia from GenBank clearly show that the latter belongs to Radomaniola. We can only speculate about the reasons for this mistake. In our phylogeny the sister taxon of H. klecakiana is Sadleriana, certainly not Radomaniola. In this case molecularly based systematics resembles the morphology-based one of RADOMAN $(1973,1983)$.

\section{ACKNOWLEDGEMENTS}

The study was supported by a grant from the National Science Centre (2012/05/B/NZ8/00407) to MAGDALENA SZAROWSKA.

\section{REFERENCES}

ANGElov A. 1967. Horatia (Hauffenia) lucidulus n. sp., ein neuer Vertreter der Mollusken Fauna Bulgariens. Arch. Moll. 96: 145-148.

ARConAdA B., RAmos M. A. 2001. New data on Hydrobiidae systematics: two new genera from the Iberian Peninsula. J. Nat. Hist. 35: 949-984. http://dx. doi.org/10.1080/002229301300323884

Bodon M., MANGANELli G., GiUSTI F. 2001. A survey of the European valvatiform hydrobiid genera, with special reference to Hauffenia Pollonera, 1898 (Gastropoda: Hydrobiidae). Malacologia 43: 103-215.

Boeters H. D. 1974. Horatia Bourguignat, Plagigeyeria Tomlin und Litthabitella Boeters (Prosobranchia). Arch. Moll. 104: 85-92.

BoETers H. D. 1998. Mollusca: Gastropoda: Superfamilie Rissooidea. Süsswasserfauna von Mitteleuropa. Begründet von A. Brauer, 5/1-2, Gustav Fischer Verlag, Jena-Lübeck-Ulm.

BOLE J. 1993. Podzemelijski polzi is druzine Horatiidae (Gastropoda, Prosobranchia) v Sloveniji in njihov taksonomski polozaj. Razprave, Slov. Akad. Znan. Umetn. Razr. Prirodos. Medic. Vede Odd. Prirodos. Vede 34: 3-11.

BOURGUIGNAT J.-R. 1887. Étude sur les noms génériques des petites paludinidées a opercule spirescent suivie de

la description du nouveau genre Horatia. V. Tremblay, Paris. http://dx.doi.org/10.5962/bhl.title.10453

DAVIS G. M., Wilke T., SPOlSKY C., QIU C.-P., QIu D.-C., XIA M.-Y., ZHANG Y., ROSENBERG G. 1998. Cytochrome oxidase I-based phylogenetic relationships among the Pomatiopsidae, Hydrobiidae, Rissoidae and Truncatelidae (Gastropoda: Caenogastropoda: Rissoacea). Malacologia 40: 251-266.

FALNIOWSKI A. 1990. Anatomical characters and SEM structure of radula and shell in the species-level taxonomy of freshwater prosobranchs (Mollusca: Gastropoda: Prosobranchia): a comparative usefulness study. Folia Malacol. 4: 53-142.

FALNIOWSKI A., SZAROWSKA M. 2011a. Genus Daphniola Radoman, 1973 (Caenogastropoda: Hydrobiidae) in the Peloponnese, Greece. Folia Malacol. 19: 131-137. http://dx.doi.org/10.2478/v10125-011-0020-9

FALNIOWSKI A., SZAROWSKA M. 2011b. A new genus and new species of valvatiform hydrobiid (Rissooidea; Caenogastropoda) from Greece. Moll. Res. 31: 189199.

FALNIOWSKI A., SZAROWSKA M. 2012. Phylogenetic position of Boleana umbilicata (Kuščer, 1932) (Caenogastropoda: Rissooidea). Folia Malacol. 20: 265-270. http://dx.doi. org/10.2478/v10125-012-0022-2 
FALNIOWSKI A., SZAROWSKA M. 2013. Phylogenetic relationships of Dalmatinella fluviatilis Radoman, 1973 (Caenogastropoda: Rissooidea). Folia Malacol. 21: 1-7. http://dx.doi.org/10.12657/folmal.021.001

FALNIOWSKI A., SZAROWSKA M., GLÖER P., PEŠIĆ V. 2012. Molecules vs morphology in the taxonomy of Radomaniola/Grossuana group of the Balkan Rissooidea (Mollusca, Caenogastropoda). J. Conch. 41: 19-36.

FALNIOWSKI A., SZAROWSKA M., SIRBU I. 2009. Bythinella Moquin-Tandon, 1856 (Gastropoda: Rissooidea: Bythinellidae) in Romania: species richness in a glacial refugium. J. Nat. Hist. 43: 2955-2973. http://dx.doi. org/10.1080/00222930903359636

FALNIOWSKI A., WILKE T. 2001. The genus Marstoniopsis (Gastropoda: Rissooidea): intra- and intergeneric phylogenetic relationships. J. Mollus. Stud. 67: 483-488. http://dx.doi.org/10.1093/mollus/67.4.483

FARRIS J. S., KÄLlERSJÖ M., KlUGE A. G., BulT C. 1995. Testing significance of incongruence. Cladistics 10:315319. http://dx.doi.org/10.1111/j.1096-0031.1994. tb00181.x

FELSENSTEIN J. 1985. Confidence limits on phylogenies: an approach using the bootstrap. Evolution 39: 783-791. http://dx.doi.org/10.2307/2408678

Folmer O., Black M., HoeH W., Lutz R. A., VRijenhoek R. C. 1994. DNA primers for amplification of mitochondrial cytochrome $\mathrm{c}$ oxidase subunit I from diverse metazoan invertebrates. Mol. Mar. Biol. Biotechnol. 3: 294-299.

GitTEnBERger E. 1982. Eine neue Horatia Art aus Griechenland (Prosobranchia: Hydrobiidae). Basteria 46: 68.

HALL T. A. 1999. BioEdit: a user-friendly biological sequence alignment editor and analysis program for Windows 95/98/NT. Nucleic Acids Symp. Ser. 41: 95-98.

Hillis D. M., MABle B. K., LARSON A., DAVIS S. K., ZimMER E. A. 1996. Nucleic acids IV: sequencing and cloning. In: HiLlis D. M., MORITZ C., MABLE B. K. (eds). Molecular systematics. 2 ed. Sinauer Associates Inc., Sunderland, Massachusetts, pp. 321-381.

KABAT A. R., HeRshler R. 1993. The prosobranch snail family Hydrobiidae (Gastropoda: Rissooidea): review of classification and supraspecific taxa. Smithson. Contrib. Zool. 547: 1-94. http://dx.doi.org/10.5479/ si.00810282.547

MADDISON D. R., MADDISON W. P. 2002. MACCLADE. Ver. 4.05. [Computer software and manual]. Sinauer Associates Inc., Sunderland, Massachusetts.

NeI M., KumAR S. 2000. Molecular evolution and phylogenetics. Oxford University press, Oxford, UK-New York.

PALUMBI S. R. 1996. Nucleic acids II: the polymerase chain reaction. In: Hillis D. M., MORITZ C., MABlE B. K. (eds). Molecular Systematics. 2 ed. Sinauer Associates Inc., Sunderland, Massachusetts, pp. 205-247.

POSADA D., BUCKLEY T. R. 2004. Model selection and model averaging in phylogenetics: advantages of Akaike Information Criterion and Bayesian approaches over Likelihood Ratio Tests. Syst. Biol. 53: 793-808. http:// dx.doi.org/10.1080/10635150490522304
RADOMAN P. 1973. New classification of fresh and brackish water Prosobranchia from the Balkans and Asia Minor. Posebna Izdanja, Prirodn. Mus. Beograd 32: 1-30.

RADOMAN P. 1983. Hydrobioidea a superfamily of Prosobranchia (Gastropoda). I Systematics. Serbian Academy of Sciences and Arts, Monographs 547, Department of Sciences 57: 1-256.

SOBER E. 2002. Instrumentalism, parsimony, and the Akaike framework. Philos. Sci. 69: 112-123. http://dx. doi.org/10.1086/341839

SCHÜTT 1961. Das Genus Horatia Bourguignat. Arch. Moll. 90: 145-152.

SWOFFORD D. L. 2002. PAUP*-Phylogenetic analysis using parsimony (* and other methods). Ver. 4. [Computer software and manual]. Sinauer Associates Inc., Sunderland, Massachusetts.

SWOFFORD D. L., OlSEN G. J., WADDELl P. J., Hillis D. M. 1996. Phylogenetic Inference. In: HILLIS D. M., MORITZ C., MABLE B. K. (eds), Molecular systematics. 2 ed. Sinauer Associates Inc., Sunderland, Massachusetts, pp. 407-514.

SZAROWSKA M. 2006. Molecular phylogeny, systematics and morphological character evolution in the Balkan Rissooidea (Caenogastropoda). Folia Malacol. 14: 99168.

SZAROWSKA M., FALNIOWSKI A. 2011. An unusual, flagellum-bearing hydrobiid snail (Gastropoda: Rissooidea: Hydrobiidae) from Greece, with descriptions of a new genus and a new species. J. Nat. Hist. 45: 2231-2246. http://dx.doi.org/10.1080/00222933.2011.591067

SZAROWSKA M., FALNIOWSKI A., RIEDEL F., WILKE T. 2005. Phylogenetic relationships of the subfamily Pyrgulinae (Gastropoda: Caenogastropoda: Hydrobiidae) with emphasis on the genus Dianella Gude, 1913. Zootaxa 891: $1-32$.

SZAROWSKA M., GRZMIL P., FALNIOWSKI A., SIRBU I. 2007. Grossuana codreanui (Grossu, 1946) and the phylogenetic relationships of the East Balkan genus Grossuana (Radoman, 1973) (Gastropoda: Rissooidea). Hydrobiologia 579: 379-391. http://dx.doi. org/10.1007/s10750-006-0530-4

Tamura K., Peterson D., Peterson N., Stecher G., NeI M., KUMAR S. 2011. MEGA5: Molecular evolutionary genetics analysis using maximum likelihood, evolutionary distance, and maximum parsimony method. Mol. Biol. Evol. 28: 2731-2739. http://dx.doi.org/10.1093/ molbev/msr121

TAYLOR D. W. 1966. A remarkable snail fauna from Coahuila, México. Veliger 9: 152-228.

THOMPson J. D., GiBson T. J., Plewniak F., JeANMOUgin F., HIGGINS D. G. 1997. The ClustalX windows interface: flexible strategies for multiple sequence alignment aided by quality analysis tools. Nucleic Acids Res. 24: 4876-4882. http://dx.doi.org/10.1093/ nar/25.24.4876

WiLKE T., DAVIS G. M. 2000. Infraspecific mitochondrial sequence diversity in Hydrobia ulvae and Hydrobia ventrosa (Hydrobiidae: Rissoacea: Gastropoda): Do their different life histories affect biogeographic patterns and 
gene flow? Biol. J. Linn. Soc. 70: 89-105. http://dx.doi. org/10.1111/j.1095-8312.2000.tb00202.x

WiLKE T., DAVIS G. M., FALNIOWSKI A., GIUSTI F., BODON M., SZAROWSKA M. 2001. Molecular systematics of Hydrobiidae (Gastropoda: Rissooidea): testing monophyly and phylogenetic relationships. Proc. Acad. Nat. Sci. Philadelphia 151: 1-21. http:// dx.doi.org/10.1635/0097-3157(2001)151[0001: MSOHMG]2.0.CO;2

Wilke T., Davis G. M., GONG X., LIU H. X. 2000. Erhaia (Gastropoda: Rissooidea): phylogenetic relationships and the question of Paragonimus coevolution in Asia. Am. J. Trop. Med. Hyg. 62: 453-459.

WiLKe T., FALNIOWSKI A. 2001. The genus Adriohydrobia (Hydrobiidae: Gastropoda): polytypic species or polymorphic populations? J. Zool. Sys. Evol. Res. 39: 227-234. http://dx.doi.org/10.1046/j.14390469.2001.00171.x
Wilke T., HaAse M., Hershler R., LiU H. P., Misof B., PONDER W. 2013. Pushing short DNA fragments to the limit: Phylogenetic relationships of "hydrobioid" gastropods (Caenogastropoda: Rissooidea). Mol. Phylogenet. Evol. 66: 715-736. http://dx.doi. org/10.1016/j.ympev.2012.10.025

XIA X. 2000. Data analysis in molecular biology and evolution. Kluwer Academic Publishers, Boston, Dordrecht \& London.

Xia X., Xie Z., SAlemi M., Chen L., Wang Y. 2003. An index of substitution saturation and its application. Mol. Phylogenet. Evol. 26: 1-7. http://dx.doi.org/10.1016/ S1055-7903(02)00326-3

Received: August 26th, 2013

Revised: December 14th, 2013

Accepted: December 23rd, 2013

Published on-line: February 9th, 2014 